\title{
Piotr SŁONIMSKI.
}

\section{Chromogaster testudo La u t e n born (Rotato- ria, Plö̈ma) na Polesiu.}

Chromogaster testudo La u t e nborn (Rotatoria, Ploüma) aus Polesien.

W roku 1893 opisał R. Lauten born w pracy, dotyczącej fauny wrotków (Rotatoria) Renu i jego łach, nowy rodzaj z rzędu Ploïma (Loricata) z jedynym gatunkiem Chromogaster testudo.

W tym samym czasie, a nawet trochę wcześniej (por. H. S. Jennings ${ }^{1}$ ), opisał Bergendal bardzo zbliżonego do wyodrębnionego przez Lautenborn'a przedstawiciela rodzaju Chromogaster - nowego wrotka Anapus ovalis.

W świetle dalszych poszukiwań oba rodzaje okazały się identycznemi (Cf. Harring, 1913), jednak wyodrębnione przez Bergendal'a i La utenborn'a gatunki różniły się nieco swemi cechami. Tylko nieliczni autorzy, jak Jennings (1894), Woronkow (1907), sądzili, iż Chromogaster testudo La utenborn stanowi synonim Anapus ovalis Bergendal.

Większość badaczy, a między niemi Dieffen bach (1912), Harring (1913), Weber i Montet (1918), uznaja natomiast Chromogaster testudo La ut. ${ }^{2}$ ) za samoistny gatunek.

1) "It is difficult to tell what this animal should be called, apparently Bergendals name (Anapus) was the first published (1892), but almost without description; the first description being published by $\mathrm{L}$ a u $\mathrm{te} \mathrm{n}$ b o r $\mathrm{n}$ with the name Chromogaster testudo (1893)* (Cf. H. S. Je nnings, 1894, Bull. of the Michig. Fish Commission, si 3).

$\left.{ }^{2}\right)$ Zgodnie z Harring'a (1913) „Synopsis of the Rotifera“ nazywam rodzaj ten Chromogaster, a nie Anapus. 
Ciekawego tego wrotka znalazłem w moich materjałach poleskich, zgromadzonych w lipcu i sierpniu 1913 r. Wobec tego, że znaleziona przeze mnie niewielka ilość egzemplarzy Chromogaster testudo Laut. nie pozwala mi na bardziej wyczerpującą analizę morfologiczno-systematyczną wspomnianej formy, ograniczam się tymczasem do podania w tej notatce wiadomości o znalezieniu Chromogaster testudo La utenborn w próbkach, pochodzących $\mathrm{z}$ następujących miejsc na Polesiu:

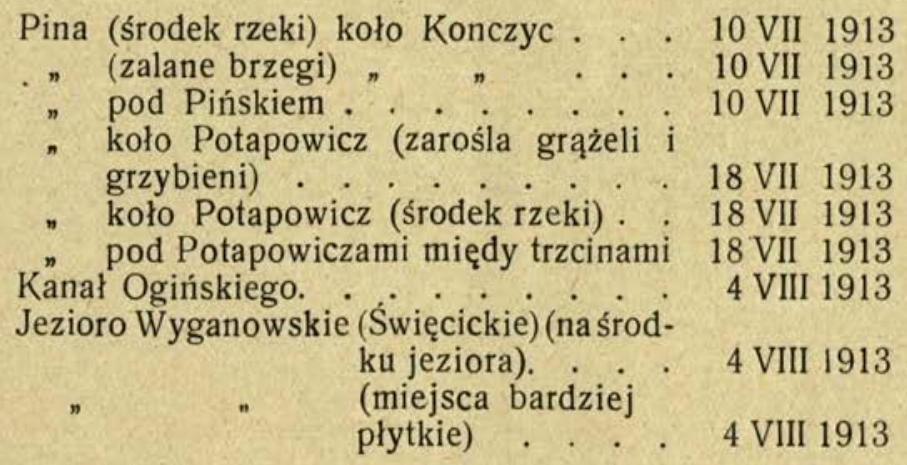

Pod względem ekologicznym stwierdzone przeze mnie miejsca występowania Chromogaster testudo Laut. nie odbiegają od znanych stanowisk tego wrotka w innych krajach (Niemcy Lautenborn, Dieffenbach etc.). Zarówno jednak Woronkow (1909), jak i ostatnio L. Wiszniewski (1930) nie notuja tego gatunku w swych wykazach systematycznych wrotków Polesia. Jest to teren bardzo ciekawy i bogaty pod tym względem.

W moich materjałach, zbieranych w miesiacach letnich (lipiec-sierpień, 1913), udało mi się w próbkach, pochodzących tylko z rzeki Piny, wykryć 98 form wrotków (z tego 72 niewyróżnionych przez mego poprzednika Woronkowa). Jest to ilość, dorównywujaca prawie ogółowi znanych form wrotków ze wszystkich wód płynących w Polsce (Słonimski ${ }^{1}$ ). Opierając się na znanych mi źródłach, dotyczących występowania wrotków w Pol-

1) Opracowanie części moich materjałów, dotyczących fauny wrotków Polesia, zestawiłem w pracy p. t. "Zarys fauny wrotków (Rotatoria) rzeki Piny i kanału Ogińskiego na Polesiu*. Z przyczyn w dužej mierze ode mnie niezaležnych, praca ta, mimo przedstawienia jej na posiedz. Tow. Nauk. Warsz. w r. 1922, nie ukazała się dotąd w druku. 
sce, mogę uważać stwierdzenie występowania Chromogaster testudo Lautenborn (1893) na Polesiu za wzbogacenie fauny wrotków krajowych o nowy gatunek.

\section{LIT E RA T UR A ${ }^{1}$ ).}

B e r g e n da 1, O. 1893. Öfversigt af Kongl. Vetenskaps. Akad. Förhandlingar № 9 (str. 589).

Di eff e n b a ch, H. 1912. Rotatoria, Fam. Anapodidae, w „Die Süsswasserfauna Deutschlands“, Heft 14, str. 235-6.

H a rring, H. K. 1913. Synopsis of the Rotatoria. Bull. Unit. Stat. Nation. Museum (81).

Jakubski, A W. 1915. Opis fauny wrotków (Rotatoria) powiatu Sokalskiego $\mathrm{z}$ uwzględnieniem gromad brzuchorzęsków (Gastrotricha) etc. Rozprawy i Wiadomości z Muzeum im. Dzieduszyckich. T. 1. Zesz. 3-4.

L u cks, R. 1912. Zur Rotatorienfauna Westpreussens. Westpr. Bot.-Zool. Ver. Danzig.

Jennings, H. S. 1894. Bull of the Michigan Fish Comm. № 3.

La ut enborn, R. 1893. Beiträge zur Rotatorienfauna des Rheins und seiner Altwasser. Zool. Jahrb. Abt. f. Syst. Band 7. (por. str. 266, tabl. 11 , ryc. 7 i 8 ).

We b er, E. 1898. Faune rotatorienne du bassin du Léman. Revue Suisse de Zoologie. T. 5, p str. 76 , tabl. XXIV, ryc. 15-17.

We ber, E. et M on te t, G. 1918. Cat. des Invert. de la Suisse. Fasc. 11 (Rotateurs). Genève.

Wis zni e wski, J. 1930. Przyczynek do znajomości fauny wrotków Polesia. Arch. Hydrobiol. i Rybactwa. T. 5, str. 265-284.

Woronk ow, N. W. 1907. Kołowratki Moskowsk. Gubern. Trudy Gidrobiol. Stancii na Głub. Oz. T. 2.

- 1909. K faunie Rotatoria Minskoj gub. Trudy Stud. Kruzka Izsl. Russ. Prir. T. 4 (odbitka).

\section{ZUSAMMENFASSUNG.}

Der Verfasser berichtet über den Fund eines für Polen neu. en Rädertiers Chromogaster testudo La ut en born (1893) (in vereinzelten Exemplaren) im Flusse Pina, im Ogiński-Kanal, wie auch im Wyganowski-See in Polesien (Juli, August 1913).

1) Uwzględniam tylko prace, najściślej związane z treścią tej notatki. 


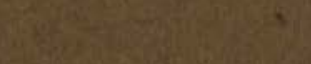

(x)

3. $30 x y$

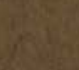

http://rcin.org.pl 
http://rcin.org.pl 